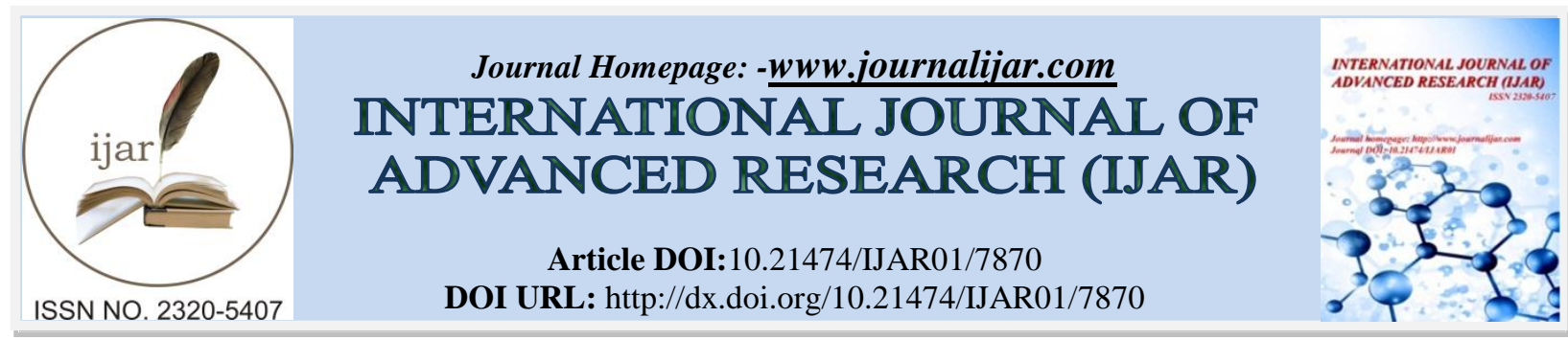

RESEARCH ARTICLE

\title{
CORRELATION BETWEEN THE EARLY MID-TRIMESTER (13-20 WEEKS) MATERNAL SERUM BETA-HCG LEVELS AND THE DEVELOPMENTOF GESTATIONAL HYPERTENSION LATER IN THE PREGNANCY, A PROSPECTIVE OBSERVATIONAL STUDY.
}

\author{
Dr. Basharat Hussain Pandit ${ }^{1}$, Dr. Sadia Ali Wani ${ }^{2}$, Dr. Syed Nawaz Ahmad ${ }^{3}$, Dr. Asia Ashraf ${ }^{4}$, Dr. Manjeet \\ Arora ${ }^{5}$ and Dr. Shelly Batra ${ }^{5}$. \\ 1. PG Resident Department of Obstetrics and Gynaecology, Batra Hospital New Delhi, India. \\ 2. Senior resident Anaesthesiology Hamdard Institute of Medical Sciences, New Delhi, India. \\ 3. Senior resident Department Of Obstetrics and Gynaecology, ESIC Postgraduate Institute of Medical Sciences \\ and Research, New Delhi, India. \\ 4. PG resident in the Department Of Obstetrics and Gynaecology, GMC Srinagar. \\ 5. Consultant Department of Obstetrics and Gynaecology Batra Hospital, New Delhi, India.
}

\section{Manuscript Info}

Manuscript History

Received: 9 August 2018

Final Accepted: 11 September 2018

Published: October 2018

Keywords:-

Mid-trimester $\beta \mathrm{hCG}$, gestational

hypertension, pre-eclampsia, eclampsia maternal mortality.

\section{Abstract}

Background: Gestational hypertension is a common but potentially life threatening complication of pregnancy. Till date no accurate diagnostic modalities are available for its early prediction so that adequate timely measures could be taken for prevention, early detection and adequate management.

Objective: To evaluate the role of mid-trimester maternal serum $\beta \mathrm{hCG}$ levels for the prediction of development of pre-eclampsia and its severity later in the pregnancy.

Methods: The study was a prospective observational study involving a total of 178 randomly selected women, between 13 to 20 weeks of gestation. Early mid-trimester $\beta$ hCG levels were estimated and absolute values converted to population based multiples of median (MOM) and development and severity of hypertension/pre-eclampsia was observed in the follow up.

Results: Out of a total of 178 only 165 women could be followed till end. Among 142 women with mid-trimester $\beta$ hCG levels $<2$ MOM only 2 developed hypertension. Twenty three women had $\beta$ hCG values $>2 \mathrm{MOM}$ and in this group $47.8 \%$ women developed severe hypertension $(\mathrm{p}<0.001)$. A positive correlation between the severity of hypertension and absolute $\beta \mathrm{hCG}$ levels more than $80000 \mathrm{mIU} / \mathrm{mL}$ $(88935 \pm 7835.44 ; \mathrm{t}=6.058 ; \mathrm{p}<0.001)$ was observed. The chances of caesarean delivery increased with the severity of hypertension. Whereas only $20.6 \%$ normotensive women were delivered by LSCS; $11(55.0 \%)$ out of a total of 20 women with gestational hypertension underwent LSCS ( $\mathrm{p}<0.001)$.

Conclusion: Elevated mid-trimester maternal serum $\beta \mathrm{hCG}$ levels could be used as a predictor of development and severity of hypertension in pregnancy. 


\section{Introduction:-}

Hypertensive disorders in pregnancy form a wide spectrum, including gestational hypertension, pre-eclampsia, eclampsia, chronic hypertension and chronic hypertension with superimposed pre-eclampsia. Hypertensive disorders affecting pregnancy are common and form the deadly triad along with hemorrhage and infarction, which contribute greatly to feto-maternal morbidity and mortality. The pathophysiological trigger for the disease process is thought to be abnormal placentation which is supported by the recent placental transcriptome theory. ${ }^{[1,2]}$ It is hypothesized that during mid-trimester, immunological changes occur in the trophoblasts, resulting in secretory response, which reflects as a rise in the maternal serum $\beta$ hCG levels.

Human Chorionic Gonadotropin (hCG) is a glycoprotein with biological activity similar to luteinizing hormone (LH). It is produced almost exclusively in placenta but also in small quantity in fetal kidney, malignant tumors and anterior pituitary. Human Chorionic Gonadotropin is detectable in serum 7-9 days after luteinizing hormone (LH) surge that precedes ovulation, and it doubles every 2 days. Its levels are highest between 60-80 days of the last menstrual period (10-12 weeks) and begin to decline thereafter to reach a nadir around 20 weeks, and are maintained till term.

Numerous tests have been tried for the prediction of development of gestational hypertension but none of them has been promising. In a recent study role of 47 different maternal serum biomarkers was evaluated for early prediction of pre-eclampsia between 14-16 weeks of gestation and samples from the Screening for Pregnancy Endpoints (SCOPE) consortium ( $\mathrm{N}=5623$ women) were used. ${ }^{[3]}$ Among the markers evaluated, placental growth factor was found to have modest predictive value. Similarly vasopressin and serum leptin levels have also been used for the prediction of pre-eclampsia. ${ }^{[4,5]}$ All these markers have met with a little success in addition to being scarcely available and costly. Recently few researchers have used the mid-trimester maternal serum $\beta$ hCG levels as a predictor for the development and severity of gestational hypertension with some promising results. ${ }^{[6,7]}$

This study was designed to find out the usefulness of early mid-trimester maternal serum $\beta \mathrm{hCG}$ levels as a predictor and prognosticator of gestational hypertension and its severity later in the pregnancy.

\section{Methods:-}

This prospective observational study was carried out at a tertiary care super-speciality hospital in New Delhi, India after approval from the Institutional Ethical Committee for a period of one year from June 2017 to June 2018. One hundred and seventy eight, normotensive, non-proteinuric pregnant women between 13 and 20 weeks of gestational age carrying a singleton pregnancy attending the antenatal outpatient clinic were included in the study after seeking written and informed consent. Study subjects were given free will to withdraw at any point of time from the study without any repercussions. Thirteen patients were dropped out from the study due to multiple reasons which included abortions (7), fetal congenital malformations (2) and patients who didn't turn for follow up (4). Women with multiple pregnancy, hypertension, proteinuria, diabetes, congenital malformations (if included earlier) and coexistent gestational trophoblastic diseases were excluded from the study population.

Gestational age was calculated from the reliable menstrual history dates and early ultrasonographic measurement of foetal crown-rump length. Detailed relevant history was taken and clinical examination carried out and recorded. The Beta-HCG estimation in maternal serum was done by Chemiluminescent Immunometric Assay (CLIA) method (IMMULITE 2000 HCG) using 5uL of patients centrifuged serum sample. The Multiple of Median (MOM) was calculated from the median of the diagnostic test employed for the current study (Diagnostic Products Corporation, U.S, Immulite 2000-HCG), having the Central 95\% values accuracy. The absolute $\beta$ hCG levels were converted to multiples of median (MOM) of the reference population for comparative analysis.

Blood pressure measurements were taken with the women in sitting position with the cuff placed snugly on her right arm at the level of heart, with her forearm supported over a side table.

Gestational hypertension was diagnosed when the resting blood pressure was $\geq 140 / 90 \mathrm{~mm} \mathrm{Hg}$ measured on two occasions at least 6 hours apart but within 7 days after 20 weeks of gestation in a previously normotensive woman. Hypertension was said to be mild when blood pressure was $\geq 140 / 90 \mathrm{~mm} \mathrm{Hg}$ but $<160 / 110 \mathrm{~mm} \mathrm{Hg}$. Severe hypertension was defined as blood pressure $\geq 160 / 110 \mathrm{~mm} \mathrm{Hg}$ or/and abnormal serum biochemistry suggestive of end organ damage. 
All the women who developed hypertension were closely followed for the development of any alarming signs and were objectively evaluated with relevant investigations whenever needed.

The collected data was transformed into variables, coded and entered in Microsoft Excel. Data was analyzed and statistically evaluated using SPSS-PC-17 version. Quantitative data was expressed in mean; standard deviation and difference between two comparable groups were tested by student's t-test (unpaired) or Mann Whitney ' $U$ ' test while qualitative data were expressed as percentages. Statistical differences between the proportions were tested by chi- square test or Fisher's exact test. ' $P$ ' value less than 0.05 was considered statistically significant.

\section{Results:-}

Out of 178 women initially enrolled only 165 patients could be followed till conclusion of the study. Seven patients had abortion, 2 cases were excluded from the study due to diagnosis of major congenital malformations in the second trimester anatomical scan and another 4 women were lost to follow up. Majority (152) of the women were between 20-29 years of age. Twenty women (12.1\%) developed hypertension later in pregnancy. No significance for the development of hypertension could be attributed to the age of the participants (Fischer's exact test, df $=1$ ). Eighty per cent (20) of the women who developed hypertension were primigravida $(\mathrm{p}=0.01)$.

In the study participants, 142 women had serum $\beta$ hCG levels $\leq 2 \mathrm{MOM}$ and in this group only two women developed mild gestational hypertension and the rest $(98.1 \%)$ stayed normotensive throughout the pregnancy. Twenty three women were recorded to have $\beta$ hCG levels $>2$ MOM and in this group approximately half (47.8 \%) of the patients developed severe hypertension. This difference in the development of gestational hypertension was found to be statistically significant $(\mathrm{p}<0.001)$. [Table 1]

A positive correlation was observed between $\beta$ hCG levels and the severity of hypertension. Women developing mild hypertension were seen to have $\beta \mathrm{hCG}$ values less than $80000 \mathrm{mIU} / \mathrm{mL}$ (mean $\pm \mathrm{SD}=66227 \pm 16705.99$ ) while as the women developing severe hypertension had $\beta$ hCG levels more than $80000 \mathrm{mIU} / \mathrm{mL}(88935 \pm 7835.44 ; \mathrm{t}=6.058$; $\mathrm{p}<0.001)$. [Table 2]

Beta hCG as a predictor of pregnancy induced hypertension was found to be $90.0 \%$ sensitive and $96.5 \%$ specific with a positive predictive value of $78.3 \%$. [Table 3]

The chances of caesarean delivery increased with the presence and severity of hypertension. While only 30 (20.6\%) out of a total of 145 normotensive women were delivered by LSCS (lower segment caesarean section), 11 (55.0\%) out of a total of 20 women with gestational hypertension underwent LSCS (p value <0.001), indicating the need for timely and active surgical management of the patients with severe gestational hypertension. [Table 4]

\section{Discussion:-}

With every new dawn in medical sciences, our knowledge and understanding of various medical conditions has been constantly growing and every passing day increases our insight into various treatment modalities. Gestational hypertension is a forerunner of various life-threatening complications in expecting mothers like pre-eclampsia eclampsia, placental abruption, intra-cranial haemorrhage, pulmonary oedema, acute renal failure, hepatic failure, and disseminated intravascular coagulation. ${ }^{[8]}$ It can also lead to various complications in the foetus like restricted intra uterine growth, iatrogenic prematurity and intra-uterine death. ${ }^{[9,10]}$

We performed this study with the aim of evaluating the role of $\beta$ hCG as a predictor of gestational hypertension, more so for the development of early onset cases. Colour Doppler ultrasound interrogation of the uterine arteries in early pregnancy has long been used for the prediction of later pregnancy complications including pregnancy induced hypertension but its varied availability and expertise in various clinical settings limits its use. ${ }^{[1,12]}$ Moreover colour Doppler studies employing the use of persistence of diastolic notch in uterine artery waveform can only be useful after 20 weeks of gestation compared to $\beta \mathrm{hCG}$ which can be used much earlier in the pregnancy and accordingly prepare the care giver and the patient for the probable complications and hence the need for vigilance in the later part of pregnancy. Other old tests like roll over test have fallen into disrepute due to their relatively lower sensitivity. Need for a modality with certain fair degree of accuracy for the prediction of pregnancy induced hypertension has 
lead various researchers to test different tools for the same and few studies have met with some success. Our study was planned likewise to test early mid-trimester $\beta \mathrm{hCG}$ levels as a predictor of pregnancy induced hypertension.

Mid-trimester was chosen for $\beta \mathrm{hCG}$ estimation and the mean gestational age at the time of estimation was 15.45 weeks which was concordant with other studies. ${ }^{[13]}$ Confounding factors like age and other demographic variables didn't make any statistically significant difference in the mid-trimester maternal serum $\beta \mathrm{hCG}$ values though majority (20) of the women developing hypertension were primigravida ( $\mathrm{p}=0.01)$. Mid-trimester $\beta \mathrm{hCG}$ estimations are done because after 10-12 weeks of gestation $\beta$ hCG levels tend to fall to reach a nadir around 20 weeks. ${ }^{[14]}$ Pregnancies likely to be complicated by hypertension witness a rise in the serum $\beta$ hCG levels.

In our study, out of a total 165 women finally evaluated, $142(86.1 \%)$ had mid-trimester $\beta$ hCG levels $\leq 2 \mathrm{MO}$ whereas 23 women (13.9\%), had values $>2$ MOM. Out of 142 women with $\beta$ hCG levels $\leq 2 \mathrm{MOM}$, only $2(1.5 \%)$ developed pregnancy induced hypertension. And out of 23 women with $\beta$ hCG values $>2 \mathrm{MOM}, 18$ (78.3\%) developed pregnancy induced hypertension, and only $5(21.7 \%)$ stayed normotensive. The difference was found to be statistically significant $(\mathrm{p}<0.001)$. The sensitivity of this test was $90.0 \%$, specificity was $96.5 \%$ and the positive predictive value was $78.3 \%$.

The severity of hypertension was found to have a direct correlation with the absolute levels of serum $\beta$ hCG levels. Ten out of 12 women $(90.9 \%)$ with a $\beta$ hCG levels more than $80,000 \mathrm{mIU} / \mathrm{mL}$ developed severe hypertension as compared to only one patient with $\beta \mathrm{hCG}$ levels lower than $80,000 \mathrm{mIU} / \mathrm{mL}$ developing severe hypertension. This association with the absolute values of $\beta$ hCG levels was found to be statistically significant $(p<0.01)$. These observations were concordant with contemporary research. ${ }^{[6,15,16]}$ Fifty five per cent of the hypertensive women were delivered by lower segment caesarean section and among them $81.8 \%$ belonged to the severe hypertensive category. Only $28.2 \%$ normotensive women underwent lower segment caesarean section and this observation was statistically significant $(\mathrm{p}<0.001)$. Current evidence implies that mid trimester maternal serum $\beta \mathrm{hCG}$ estimation can be used with fair degree of accuracy for the prediction of gestational hypertension later in pregnancy till more cost effective and easily available and applicable methods are available in the market. Two consecutive modalities like $\beta \mathrm{hCG}$ and uterine artery Doppler may improve the prediction rates, yet this field stays vacant for the researchers to find out.

\section{Conclusion:-}

Estimation of maternal serum $\beta \mathrm{hCG}$ levels between 13 and 20 weeks of gestation is a fairly reliable and relatively cost effective method for the prediction and severity of gestational hypertension later in pregnancy. However more studies involving larger patient populations and incorporating other variables like fetal colour doppler may prove more helpful in further elucidating the correlation between the two.

\section{Funding:}

There was no funding source involved in this study.

\section{Conflict of interest:}

None.

Table 1:-Frequency distribution of the patients showing a correlation between the beta hCG levels and the development and severity of hypertension later in pregnancy

\begin{tabular}{|l|l|l|l|l|}
\hline $\begin{array}{l}\text { Beta hCG } \\
(\mathrm{MOM})\end{array}$ & $\begin{array}{l}\text { Number of cases } \\
\text { (percentage) }\end{array}$ & Normotensive (percentage) & Pregnancy Hypertension \\
\cline { 4 - 5 } & $142(86.1)$ & $140(98.5)$ & Mild (percentage) & Severe(percentage) \\
\hline$\leq 2$ & $23(13.9)$ & $5(21.7)$ & $2(1.5)$ & 0 \\
\hline$>2$ & 165 & $145(87.9)$ & $7(30.4)$ & $11(47.8)$ \\
\hline TOTAL & d.f. $=1$ & 9 & 11 \\
\hline Fisher exact test & & P-value $<0.001$ & \\
\hline
\end{tabular}

Table 2:-Frequency distribution of the women according to beta hCG levels and the severity of hypertension

\begin{tabular}{|l|l|l|l|}
\hline $\begin{array}{l}\text { Beta hCG level } \\
(\mathrm{mIU} / \mathrm{mL})\end{array}$ & Hypertension & \multirow{2}{*}{ Total (percentage) } \\
\cline { 2 - 3 } & Mild (percentage) & Severe (percentage) & $8(40.0 \%)$ \\
\hline$\leq 80000$ & $7(77.8 \%)$ & $1(9.1 \%)$ & $12(60.0 \%)$ \\
\hline$>80000$ & $2(22.2 \%)$ & $10(90.9 \%)$ & \\
\hline
\end{tabular}




\begin{tabular}{|l|l|l|l|}
\hline Total & $9(45.0 \%)$ & $11(55.0 \%)$ & $20(100.00)$ \\
\hline Fisher exact test & d.f.=1 & P-value $<0.01$ \\
\hline
\end{tabular}

Table 3:-Validity of betahCG as Predictor of Pregnancy Induced Hypertension

\begin{tabular}{|c|c|c|c|c|c|c|}
\hline Hypertension & $\begin{array}{l}\text { Test Normal } \\
(\mathrm{HCG} \leq 2) \\
\mathrm{N}=142\end{array}$ & $\begin{array}{l}\text { Test } \\
\text { Abnormal } \\
(\mathrm{HCG}>2) \\
\mathrm{N}=23\end{array}$ & $\begin{array}{l}\text { Sensitivity } \\
95 \% \text { CI }\end{array}$ & $\begin{array}{l}\text { Specificity } 95 \% \\
\text { CI }\end{array}$ & $\begin{array}{l}\text { PPV } \\
95 \% \mathrm{CI}\end{array}$ & $\begin{array}{l}\text { NPV } \\
95 \% \mathrm{CI}\end{array}$ \\
\hline Present & $\mathrm{FN}=2$ & $\mathrm{TP}=18$ & \multirow{2}{*}{$\begin{array}{l}90.0 \\
(68.3-98.8)\end{array}$} & \multirow[t]{2}{*}{$96.5(92.1-98.8)$} & \multirow{2}{*}{$\begin{array}{l}78.3 \\
(68.1- \\
89.3)\end{array}$} & \multirow{2}{*}{$\begin{array}{l}98.5 \\
99.6)\end{array}$} \\
\hline Absent & $\mathrm{TN}=140$ & $\mathrm{FP}=5$ & & & & \\
\hline
\end{tabular}

Table 4:-Distribution of women according mode of delivery, occurrence and severity of gestational hypertension

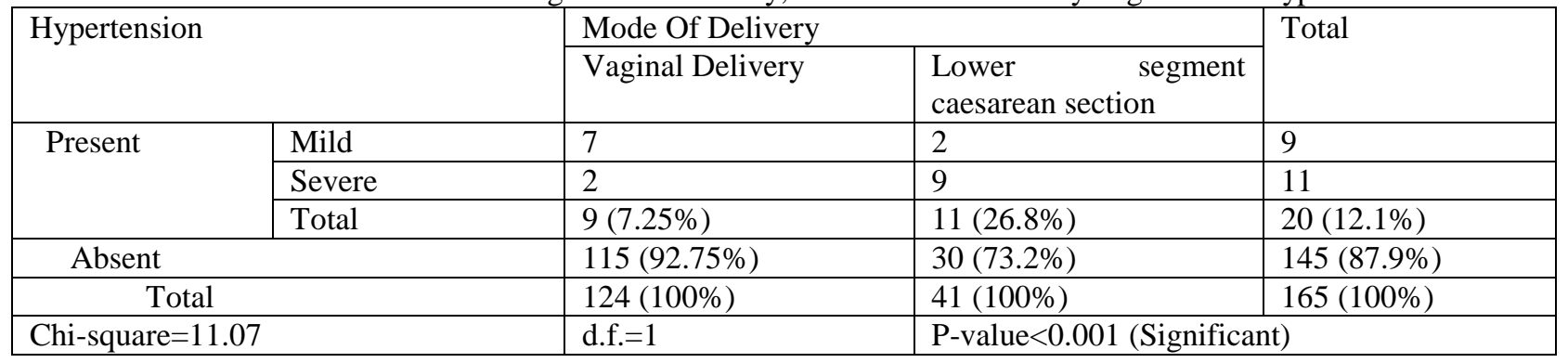

\section{References:-}

1. Sober S, Reiman M, Kika T, Rull K, Inno R, Vaas P et al. Extensive shift in placental transcriptome profile in preeclampsia and placental origin of adverse pregnancy outcomes. Sci Rep. 2015; 5:13336.

2. Kleinrouweler, C. E. et al. Differentially Expressed Genes in the Pre-Eclamptic Placenta: A Systematic Review and Meta-Analysis.PLoS One 8, e68991 (2013).

3. Kenny LC, Black MA, Poston L, Taylor R, Myers JE, Baker PN,et al. Early pregnancy prediction of preeclampsia in nulliparous women, combining clinical risk and biomarkers: the Screening for Pregnancy Endpoints (SCOPE) international cohort study. Hypertension. 2014; 64: 644- 652. doi: 10.1161/HYPERTENSIONAHA. 114.03578.

4. Santillan MK, Santillan DA, Scroggins SM, Min JY, Sandgren JA, Pearson NA, et al. Vasopressin in preeclampsia: a novel very early human pregnancy biomarker and clinically relevant mouse model. Hypertension. 2014; 64: 852- 859. doi: 10.1161/HYPERTENSIONAHA.114.03848.

5. Taylor BD, Ness RB, Olsen J, Hougaard DM, Skogstrand K, Roberts JM,et al. Serum leptin measured in early pregnancy is higher in women with preeclampsia compared with normotensive pregnant women. Hypertension. 2015; 65: 594- 599. doi: 10.1161/HYPERTENSIONAHA.114.03979.

6. Soundararajan P, Muthuramu P, Veerapandi M, Mariyappan R. Serum beta human chorionic gonadotropin and lipid profile in early second trimester (14-20 weeks) is a predictor of pregnancy induced hypertension. Int $\mathrm{J}$ ReprodContraceptObstet Gynecol. 2016; 5(9):3011-3016.

7. Sharma P, Maheshwari S, Barala S. Correlation between second trimester beta human chorionic gonadotropin levels and pregnancy outcome in high risk group. Int J ReprodContraceptObstet Gynecol. 2017; 5(7):2358-61.

8. Nankali, Sh. Malek-khosravi, M. Zangeneh, M. Rezaei, Z. Hemati, M. Kohzadi. Maternal Complications Associated with Severe Preeclampsia. J ObstetGynaecol India. 2013; 63(2):112-5.

9. Alicia M, Lapidus MD. Effects of preeclampsia on mother, fetus and child. Obgyn. net. 2011:1-3.

10. https://www.mayoclinic.org/diseases-conditions/preeclampsia/...causes/syc-20355745.

11. Su Lynn Khong, Stefan C. Kane, Shaun P. Brennecke, and Fabrício da Silva Costa, "First-Trimester Uterine Artery Doppler Analysis in the Prediction of Later Pregnancy Complications," Disease Markers, vol. 2015, Article ID 679730, 10 pages, 2015. https://doi.org/10.1155/2015/679730.

12. Singh P, Sharma B, Singh N. Early prediction of pregnancy induced hypertension by colour Doppler and role of antioxidants. Int J ReprodContraceptObstetGynecol 2016; 5: 2677- 9.

13. Chowdhary H, Khurshid R, Parveen S, Yousuf S, Tali SH, Shah ZA. Utility of second trimester beta hCG levels in prediction of gestational hypertension: a prospective cohort study. Int J ReprodContraceptObstetGynecol 2017; 6: 1040-4. 
14. Korevaar TIM, Steegers EAP, de Rijke YB, et al. Reference ranges and determinants of total hCG levels during pregnancy: the Generation R Study. European Journal of Epidemiology. 2015;30(9):1057-1066. doi:10.1007/s10654-015-0039-0.

15. Gautam SS, Kaur M, Chaudhary NK, Sharma A. Evaluation of the variations and potential clinical use of second trimester serum markers for the detection of pre-eclampsia. Int J ReprodContraceptObstetGynecol 2018; 7: 2904- 8.

16. Jindal N. Prediction of maternal serum beta hCG levels in pre-eclamptic and normotensive pregnant women. International Journal of Clinical Obstetrics and Gynaecology 2017;1(2): 34-36. 